\title{
PEMAKAIAN BIOGAS: HEMAT BIAYA BAHAN BAKAR DAN TAMBAHAN PENDAPATAN RUMAHTANGGA MENDUKUNG KETAHANAN ENERGI
}

\author{
Roosganda Elizabeth \\ Pusat Sosial Ekonomi dan Kebijakan Pertanian (PSEKP) \\ Jl. Tentara Pelajar No. 3B . Cimanggu. Bogor 16124 \\ Email: roosimanru@yahoo.com
}

\section{RINGKASAN}

Biogas diperoleh dari hasil olahan berbagai materi berbasis pertanian-ternak merupakan bioenergi terbarukan (renewable energy), solusi substitusi migas (BBM) hingga ke tingkat industri. Semakin menyusutnya minyak bumi mengharuskan akselerasi penciptaan sumber energi alternatif yang mampu memenuhi kebutuhan energi migas yang semakin meningkat seiring pesatnya pertambahan penduduk dan sektor industri. Manajemen pengolahan dan pemanfaatan limbah pertanian dan peternakan dilakukan juga untuk meminimalisir dampak negatifnya dan memaksimalkan dampak keuntungan serta tetap memperhatikan keseimbangan sistem produksi dengan lingkungan hidup (biogas tidak mengeluarkan asap). Sludge sebagai hasil ikutan merupakan biofertilizer, yang tidak lagi mengundang parasit dan biji gulma, dan pupuk alternatif solusi pencegahan berbagai dampak pencemaran logam berat pada tanah. Dengan metode deduktif kualitatif, tulisan ini bertujuan mengemukakan secara komprehensif perlunya akselerasi penggunaan biogas sebagai pemanfaatan bioenergi untuk dalam rangka mendukung ketahanan energi, pemberdayaan ekonomi dan kelembagaan. Realisasi akselerasi dan efektivitas pengaplikasian biogas sebagai sumber energi alternatif yang relatif ekonomis dan efisien, bahkan dapat menghasilkan pendapatan tambahan dari pendistribusian energi listrik yang dihasilkan biogas ke pengguna lain yang membutuhkannya. Penggunaan biogas memungkinkan pengembangan konsep zero wasted management (dalam SITT) dan pengembangan konsep pertanian berkelanjutan yang mengintegrasikan berbagai aspek sosial ekonomi masyarakat pertanian dan aspek lingkungan. Penggunaan biogas merupakan pilihan tepat sebagai bioenergi dan pupuk, serta diperolehnya keuntungan ganda (multi margin), pemberdayaan ekonomi dan kelestarian lingkungan.

Kata kunci: biogas, sludge, energy terbarukan, perbaikan ekonomi. 


\section{PERNYATAAN KUNCI}

- Pembuatan biogas merupakan diversifikasi upaya dan solusi untuk memperoleh energi dari sumbersumber energi lain yang dapat dianggap sebagai energi pengganti minyak dan gas bumi, disebut sebagai energi alternatif bahan pengganti minyak bumi. Biogas adalah bahan bakar yang bersih dan tidak mengeluarkan asap seperti halnya kayu, arang, sehingga alat-alat dapur yang digunakan tetap bersih. Dengan bahan baku yang banyak tersedia, manfaat ganda dari pembuatan biogas tersebut, yaitu berupa: gas sebagai sumber energi, sludge sebagai pupuk dan pakan, serta meningkatkan sanitasi lingkungan.

- Pembuatan biogas juga merupakan salah satu strategi penerapan dan pengembangan bioindustri untuk mendukung tercipta dan berkembangnya program hilirisasi di pedesaan. Teknologi pembuatan biogas merupakan pilihan yang tepat untuk mengubah limbah usahatani ternak menghemat pengeluaran membeli bahan bakar serta berbagai keuntungan lain secara sosial terutama dari segi ekonomi khususnya bagi rumah tangga di pedesaan. Pengembangan infrastruktur, pendidikan dan pembinaan keterampilan SDM petani, perbaikan dan peningkatan kualitas dan kemampuan (kompetensi) SDM pertanian secara serius, intensif dan berkelanjutan.

- Multi margin dari pembuatan biogas merupakan pilihan yang tepat mendukung optimalisasi pemanfaatan bioenergi, mewujudkan ketahanan energi dan pemberdayaan ekonomi dipedesaan serta kelestarian lingkungan. Perlu dikomplementasikan dengan pembenahan struktur dan efisiensi bioindustri di pedesaan sehingga pendapatan petani peternak dapat ditingkatkan dan upaya yang bersifat inklusif dan integratif dalam peningkatan kesejahteraannya.

- Pengembangan usaha bioindustri pengelola SDA dengan baik dan lestari lingkungan, baik dari aspek ekonomi, sosial dan kelestarian lingkungan dengan benar dan bijak terutama di pedesaan, mengindikasikan adanya peningkatan kualitas dan kompetensi SDM dan tentunya berdampak pada bertambahnya perolehan pendapatan yang disinyalir mampu mewujudkan kemandirian dan ketahanan pangan dan kesejahteraan petani.

- Pemberdayaan sumberdaya lahan (tanah, air, mineral dan udara), 
sumberdaya hayati (manusia, hewan, tumbuhan, dan mahluk hidup lainnya), sumberdaya lingkungan (interaksi antar mahluk), serta $6 \mathrm{M}$ (man, money, material, machine, method, management) perlu dilakukan secara sinergis dan optimal supaya seluruh stakeholders mempunyai kemauan, kemampuan, kesempatan dan kewenangan untuk berkontribusi nyata dan memperoleh manfaat optimal. Terkait dengan masyarakat sebagai pemberdayaan kelembagaan pelaku berbagai ragam usaha, terutama pelaku usahatani (petani), pelaku bioindustri, peran dan makna partisipasi (dalam berbagai program pembangunan dan kebijakan pemerintah) merupakan proses dan keadaan (situasi) dimana seluruh pihak (terutama yang terkait/berhubungan, langsung/ tidak langsung) dapat membentuk/membangun kondisi dan ikut serta terlibat serta kooperatif dalam seluruh inisiatif, tahapan dan aktivitas pembangunan.

- Dalam pemberdayaan kelembagaan dan partisipasi, siapapun dapat berperan aktif, baik berperan dalam bermasyarakat, dalam kehidupan sendiri, terlebih lagi keterlibatan untuk berperan dalam pembangunan. Meski memiliki makna yang berbeda- beda (tergantung pada "apa" dan "bagaimana" mereka turut serta terlibat), namun pada akhirnya partisipasi bertujuan untuk increasing self-determination (meningkatkan kemandirian/keteguhan diri), serta terkontruksinya/terbangunnya kontrol (build construction control) dan inisiatif masyarakat terhadap pengelolaan sumberdaya untuk pembangunan.

\section{REKOMENDASI KEBIJAKAN}

- Perencanaan dan pelaksanaan pembangunan pertanian di pedesaan, hendaknya ditekankan perbaikan dan pembenahan ragam bioindustri yang mampu memotori industrialisasi perdesaan, yang berdayaguna dan berhasilguna serta ke arah peningkatan pendapatan, kesempatan kerja dan berusaha di perdesaan.

- Perlunya keseragaman dan kesepakat bersama/komitmen masing-masing para pemangku kebijakan di tingkat pusat hingga tingkat daerah, sehingga dapat membantu kelancaran dalam koordinasi dan pelaksanaan program kerja di daerah. Dibutuhkan berbagai regulasi dan kelembagaan yang mewadahi berbagai kegiatan bioindustri mulai dari sisi produksi, pengolahan, pemasaran dan keberlanjutannya. 
- Perlunya dukungan peningkatan dan pengembangan teknologi biogas sebagai salah satu bioindustri di pedesaan untuk penganekaragaman produksi dan kesempatan bekerja dan berusaha di bidang industri berbasis pertanian.

- Perlunya keberpihakan dan dukungan kepada petani dan kelompok tani sebagai pemberdayaan kelembagaan di pedesaan dengan program kebijakan pelatihan dan bimbingan teknologi secara intensif dan berkesinambungan untuk mewujudkan penguatan pengolahan berbasis pertanian, termasuk limbah pertanian dari subsistem hulu (budidaya) sampai dengan subsistem hilir (pemasaran dan menjadi pelaku usaha produk olahan) sesuai dengan konsep value chain market based solution.

\section{PENDAHULUAN}

Beberapa aspek trend yang memiliki konsekuensi dan solusi, terkait pertanian masa depan, yaitu: (i) perlunya upaya mendorong transformasi ekonomi ke bioenergi sebagai antisipasi semakin langkanya energi fosil; (ii) semakin urgensinya bioproduk, pola hidup sehat, dan pola konsumsi biokultur seiring semakin meningkatnya kebutuhan pangan, pakan, energi dan serat; (iii) perlunya dorongan peningkatan kapasitas adaptasi dan mitigasi untuk mengantisipasi perubahan iklim global; (iv) keharusan pada keniscayaan untuk kegiatan efisiensi dan konservasi sebagai antisipasi dampak terjadinya kelangkaan lahan dan air; (v) pengembangan sistem pertanian ekologis dan bioservices sebagai dorongan dari permintaan terhadap jasa lingkungan hidup; (vi) perlunya penerapan pluriculture sistem biosiklus terpadu sebagai dampak meningkatnya petani marginal; (vii) pengembangan bioekonomi sebagai dampak yang diberikan dari kemajuan Iptek bioscience dan bioengineering. Dibutuhkan penanganan yang holistik dengan integrasi seluruh pemangku kepentingan dan menyikapinya dengan perubahan dan pembaharuan paradigma pembangunan perekonomian nasional, ke arah: (i) paradigma pertanian untuk pembangunan (agriculture for development), pembangunan perekonomian nasional perlu dirancang dan dilaksanakan sesuai tahapan pembangunan pertanian serta mendudukkan sektor pertanian sebagai motor penggerak transformasi pertanian yang berimbang dan menyeluruh; (ii) paradigma sistem pertanian-bioindustri berkelanjutan, dengan pengalihan industri yang berbahan bakar fosil ke bahan bakar terbarukan (hayati).

Paradigma tersebut mendudukkan peran pertanian sebagai penghasil berbagai bioenergi, dan biomassa bahan baku biorefinery untuk menghasilkan pangan, pakan, serat, energi, (food, feed, fiber, energi), 
dan berbagai bioproduk lainnya, dan lingkungan (environment); yang merupakan isu global pembangunan pertanian yang harus dihadapi sebagai tantangan untuk dapat mengembangkan pertanian ramah lingkungan dengan penerapan teknologi melalui pengembangan bio-science, inovasi menghadapi perubahan iklim (GCC innovation respon), dan bio-informatik yang mengaplikasikan teknologi informasi (bioinformation) dengan selalu mengedepankan kelestarian lingkungan dan SDA (Wahyunto, 2005. Hambali, 2004. dalam: Elizabeth, 2017). Pengimplementasian pembuatan biogas, mendukung pengembangan program hilirisasi dengan konsep pertanian-bioindustri yang terkait erat dengan terdapatnya minimal lima tantangan yang dihadapi sektor pertanian saat ini. Kelima tantangan tersebut, meliputi: 1) peningkatan pendapatan petani yang mayoritas berlahan kurang dari 0,5 hektar; 2) tantangan agronomis, untuk meningkatkan produksi pangan dan komoditas pertanian; 3) tantangan demografis, untuk memenuhi kebutuhan pangan penduduk yang terus bertumbuh; 4) tantangan menghadapi perubahan iklim global untuk mewujudkan pertanian berkelanjutan; 5) tantangan untuk memfasilitasi proses transformasi perekonomian nasional dari berbasis fosil ke bioekonomi.
Pengembangan pertanian terintegrasi ternak (ruminansia dan unggas) yang inovatif semakin diperlukan seiring semakin menciutnya areal tanam akibat konversi lahan ke tujuan ekonomi lainnya (perdagangan, perumahan, industri, dan sebagainya). Indonesia memiliki berbagai sumberdaya genotip (SDGS) yang berlimpah sebagai bahan baku. Material berbasis pertanian berpotensi besar untuk menjadi bahan baku bioindustri, serta mampu menghasilkan berbagai jenis bioenergi seperti: biogas, biodiesel, bioetanol, biolistrik dan bioavtur yang dihasilkan dari proses pengolahan lanjutan. Pengimplementasiannya terus ditingkatkan seiring perolehan dan aplikasi penggunaannya yang pemakaiannya untuk meminimalisir penggunaan BBM. Pengolahan berbagai produk dan limbah berbasis pertanian yang dapat menghasilkannya, dari hasil sintesis dan hasil penyulingan berbagai produk berbasis pertanian lainnya termasuk dari kotoran hewan ternak (sapi, kerbau, kuda, kambing, dan ternak lainnya) (Sutisna. 2015). Seiring dengan kian menyusutnya minyak bumi yang masih menjadi salah satu sumber energi utama, berbagai bahan dan materi berbasis pertanian dapat diolah lebih lanjut untuk menghasilkan bioenergi pensubstitusi bahan bakar minyak (BBM). Upaya tersebut juga yang ditujukan untuk meningkatkan produksi minyak bumi (misalnya surfaktan 
dari hasil sintesis minyak sawit) (BBIA, 2014. Kasryno, 2013. dalam: Hambali et al, 2014).

\section{SITUASI TERKINI}

Dengan semakin menyusutnya minyak bumi yang masih menjadi salah satu sumber energi utama, berbagai bahan dan materi berbasis pertanian dapat diolah lebih lanjut untuk menghasilkan bioenergi pensubstitusi bahan bakar minyak (BBM) dan atau yang ditujukan untuk meningkatkan produksi minyak bumi (misalnya surfaktan dari hasil sintesis minyak sawit) (BBIA, 2014. Kasryno, 2013. dalam: Hambali et al, 2014). Indonesia memiliki berbagai sumberdaya genotip (SDGS) yang berlimpah sebagai bahan baku yang mampu menghasilkan berbagai jenis bioenergi seperti: biogas, biodiesel, bioetanol, biolistrik dan bioavtur yang dihasilkan dari proses pengolahan lanjutan. Pengimplementasiannya terus ditingkatkan seiring perolehan dan aplikasi penggunaannya yang pemakaiannya untuk meminimalisir penggunaan BBM. Material berbasis pertanian berpotensi besar untuk menjadi bahan baku bioindustri.

Pembuatan biogas dengan mengolah berbagai bahan dan materi berbasis pertanian-peternakan, juga merupakan salah satu strategi penerapan dan pengembangan bioindustri untuk mendukung tercipta dan berkembangnya program hilirisasi di pedesaan (Elizabeth, 2018). Multi margin diperoleh dengan adanya tambahan pendapatan petani dari pendistribusian biogas, sludge sebagai pupuk (biofertilizer) dan pakan. Biogas merupakan bioenergi dan energi terbarukan (renewable energy) unggul dan penting dalam rangka optimalisasi pemanfaatan bioenergi untuk ketahanan energi, pemberdayaan ekonomi dan kelembagaan (Elizabeth, 2018). Biogas, diharapkan sebagai salah satu solusi yang mampu mensubstitusi kebutuhan migas (BBM) hingga ke tingkat industri. Pengembangan manajemen pengolahan dan pemanfaatan limbah pertanian dan peternakan dilakukan juga untuk meminimalisir dampak negatifnya dan memaksimalkan dampak keuntungan serta tetap memperhatikan keseimbangan sistem produksi dengan kelestarian lingkungan (biogas tidak mengeluarkan asap).

Untuk mengatasi permasalahan semakin tingginya biaya bahan bakar, dengan metode deskriptif kualitatif, tulisan ini bertujuan mengemukakan secara komprehensif akselerasi penggunaan biogas dalam rangka mendukung optimalisasi pemanfaatan bioenergi untuk ketahanan energi, pemberdayaan ekonomi dan kelembagaan. Biogas sebagai sumber bioenergi penghasil listrik dan gas dalam rangka mendukung strategi mengatasi masalah biaya ekonomi rumah tangga di pedesaan, dan energi penggerak peralatan industri. Realisasi akselerasi dan efektivitas 
pengaplikasian biogas sebagai sumber energi alternatif yang relatif ekonomis dan efisien untuk mendukung optimalisasi pemanfaatan bioenergi, bahkan dapat menghasilkan pendapatan tambahan dari menjual energi listrik yang dihasilkan biogas ke konsumen yang menginginkannya. Penggunaan biogas memungkinkan pengembangan konsep zero wasted management dalam SITT. Peningkatan implementasi bioindustri untuk menghasilkan dan optimalisasi bioenergi melalui pemanfaatan limbah pertanian ternak untuk penggunaan domestik, bahan pangan, serat, energi bioenergi/energi alternatif), pupuk organik cair, pangan fungsional, pakan ternak (sapi penggemukan) dan perikanan.

Pengolahan berbagai produk dan limbah berbasis pertanian yang dapat menghasilkannya, dari hasil sintesis dan hasil penyulingan berbagai produk berbasis pertanian lainnya termasuk dari kotoran hewan ternak (sapi, kerbau, kuda, kambing, dan ternak lainnya) (Sutisna, 2015). Di beberapa daerah di berbagai wilayah pedesaan sudah sering ditemukan pengaplikasian dan pemanfaatan biogas sebagai sumber energy (mengaktifkan/mengoperasikan dan menjalankan alat-alat pertanian dan industry pertanian), sumber energy substitusi listrik dan bahan bakar rumahtangga (memasak).
Sementara itu, sebagai pegangan, pemantau dan pengawal dalam terlaksana dan suksesnya suatu program pembangunan, diperlukan partisipasi dalam monitoring dan evaluasi (participatory monitoring and evaluation = PM\&E); yang berupaya melibatkan (to engage) pihak-pihak stakeholders utama untuk lebih aktif dalam merefleksikan dan mengukur (assesing) kemajuan proyek dan terutama pencapaian hasil. Untuk itu, pelaksanaan program pembangunan hendaknya tetap menjalankan prinsip utama PM\&E, yaitu: 1) stakeholders utama adalah partisipan yang aktif tidak hanya sebagai sumber informasi; 2) membangun dan mengembangkan kemampuan masyarakat setempat untuk menganalisa, merefleksikan dan berperan aktif/mengambil bagian; 3) terjadinya proses belajar bersama (joint learning) dari seluruh stakeholders pada berbagai level; dan 4) adanya komitmen untuk terciptanya proses yang lebih tepat dan multi guna. Dengan demikian, dasar terpenting dibutuhkannya partisipasi adalah agar terjaminnya pembangunan bioindustri berkelanjutan karena sangat tergantung pada social process dan terkait dengan tiga aspek utama masyarakat (sosial, ekonomi dan lingkungan) tersebut di atas. Hal tersebut juga membuat penduduk pedesaan berangsur-angsur bisa melepaskan diri dari jebakan paradox of plenty (kondisi dimana 
suatu negara yang kaya sumberdaya alam tetapi rakyatnya miskin) (Fauzi, 2014).

Demikian juga halnya bila dikaji dari aspek keberlanjutan, pengusahaan biogas yang sudah cukup baik dan tidak memiliki dampak negatif, namun masih relatif kurang dari sisi pemasaran dan distribusi energi biogas sebagai subsistem aktivitas bisnis dari produk hasil suatu usaha, diarahkan pada perbaikan mekanisme berbagai pendekatan yang umum berlaku dalam aktivitas suatu usaha pengolahan (Elizabeth, 2018a). Kelompok tani ternak merupakan salah satu wadah berbentuk kelembagaan yang memiliki peran penting di pedesaan. Lembaga di pedesaan lahir untuk memenuhi kebutuhan sosial masyarakatnya (Elizabeth, 2014). Sifatnya tidak linier, namun cenderung merupakan kebutuhan individu anggotanya, antara lain berupa kebutuhan: fisik, rasa aman (savety), hubungan sosial (social affiliation), pengakuan (esteem), pengembangan pengakuan (self actualization).

Pendukung utama terlaksananya upaya pencapaian pengembangan pengusahaan dan penggunaan biogas, sangat diperlukan ketersediaan perangkat kebijakan yang memadai, teknologi dan informasi yang dibutuhkan, serta berfungsinya lembaga pendukung lainnya seperti: penyuluhan, pemasaran, dan sistem pendekatan instansi terkait (Elizabeth, 2008). Lemahnya kinerja lembaga penyuluhan di pedesaan salah satunya dapat mengakibatkan informasi harga umumnya hanya diperoleh dari sesama petani, pedagang, pasar, dan media massa (Elizabeth, 2017a). Kondisi tersebut mengindikasikan diperlukan penanganan, pembinaan dan sosialisasi manfaat dan multi fungsi keuntungan pengusahaan dan penggunaan biogas. Oleh karena itu diperlukan peran aktif dan keberpihakan semua pihak terkait, dengan kontinuitas pengarahan, bimbingan, dan sosialisasi dari pihak penyuluh lapang terhadap petani peternak akan manfaat dan multi fungsi serta keuntungan pengusahaan dan penggunaan biogas (Elizabeth, 2016).

Penerapan metode Integration Farming System (IFS), Crops-Livestock System (CLS), dan Organic and Un-Organic Farming mendorong pengembangan pertanian secara intensif dan terintegrasi (BPPT, 2005). Pemanfaatan limbahnya dengan membuat biogas agar multi margin dengan diperolehnya penambahan pendapatan petani hasil pembuatan biogas (zero waste) tidak sekedar dibuang atau dibakar dan menjaga kelestarian lingkungan. Biogas merupakan sumber energi terbarukan (renewable energy) penting sebagai substitusi unggul dan mampu menyumbangkan andil untuk memenuhi kebutuhan bahan bakar rumah tangga (kontribusi dan efisiensi biaya listrik dan gas) (Haryono, 2014). Pengelolaan limbah pertanian-ternak dilakukan untuk meminimalisir dampak 
negatifnya dan memaksimalkan dampak keuntungan serta tetap memperhatikan keseimbangan sistem produksi dengan lingkungan hidup. Beberapa hasil penelitian telah mengemukakan berbagai potensi limbah biomasa di seluruh Indonesia. Biomasa seperti kayu, dari kegiatan industri pengolahan hutan pertanian dan perkebunan (Tuti, 2008). Besarnya energi yang dihasilkan dari pengolahan limbah biomasa tersebut bisa mencapai kisaran 49.907, 43 MW. Namun, tidak semua pedesaan yang memiliki atau berdampingan dengan hutan, dan mayoritas berpenghasilan dari usahatani dan ternak

$$
\text { Terdapatnya tiga prinsip }
$$

keberlanjutan sistem pertanian terkait bioenergi dan bioindustri di pedesaan sebagai dukungan untuk mengoptimalkan ketahanan energi, yang meliputi: 1) self financing: membiayai sendiri sebisa mungkin melalui usaha yang saling menunjang dan berjenjang; 2) menerapkan teknologi skala kecil; dan 3) usaha yang layak teknis dan ekonomis (Lidjang et al, 2015). Integrasi sapi perah dengan kelapa sawit yang menghasilkan susu, minyak sawit, biogas (hasil fermentasi kotoran sapi), dan pludge yang merupakan pupuk organik, di Provinsi Aceh dapat dijadikan contoh penerapan tiga prinsip tersebut (Ilham et al, 2018). Terkait ketiga prinsip tersebut, Sistem PertanianEnergi Terpadu (SPET) yang menjadi titik berat Pembangunan Pertanian-Bioindustri tahap pertama, pada subsistem usahatani primer didasarkan pada inovasi bioteknologi yang mampu menghasilkan biomassa setinggi mungkin untuk dijadikan sebagai feedstock penghasil bioenergi; dan untuk mencegah trade-off ketahanan pangan dan ketahanan energi maka SPET pada subsistem bioindustri didasarkan pada inovasi bioengineering untuk mengolah feedstock menjadi energi dan bioproduk, termasuk pupuk untuk usahatani.

$$
\text { Beberapa hasil penelitian }
$$
mengemukakan seekor sapi potong dewasa rata-rata dapat menghasilkan kotoran minimal sekitar 10\% dari bobot tubuhnya. Bila dalam satu kandang kolektif dipelihara 3-5 ekor sapi potong, maka sekitar 100$2.000 \mathrm{~kg} /$ hari kotoran yang terkumpul. Bisa diperhitungkan nilai ekonomi yang diperoleh dari kotoran ternak sebagai limbah pemeliharaannya tersebut, baik dalam bentuk kotoran secara langsung, terlebih setelah diolah yang salah satunya adalah biogas dan sludge sebagai hasil ikutannya. Namun sampai saat ini kotoran sapi dan limbah hasil pertanian masih belum dimanfaatkan sepenuhnya oleh petani, dan umumnya di buang ke saluran air untuk memudahkan penanganan dan untuk lahanlahan yang terairi oleh saluran tersebut. Limbah tanaman pangan dibuang atau dibakar, meski dengan hasil pembakarannya di maksudkan untuk kesuburan tanaman kembali. Namun, kotoran ternak segar 
belum dapat diaplikasikan langsung pada tanaman, karena harus dingin/didiamkan dan terkomposisi dengan rasio $\mathrm{C} / \mathrm{N}$ lebih dari 40 .

Energi dari bahan bakar, merupakan faktor penting yang aspeknya sangat vital sebagai sumber bagi keberlangsungan dan keberlanjutan kehidupan, dan pemenuhannya berpengaruh besar bagi berlangsungnya berbagai aktivitas ekonomi. Disamping energi hasil dari bahan bakar, pangan, merupakan kebutuhan pokok yang hakiki dan HAM serta sebagai salah satu sumber penghasil energi, tenaga dan kekuatan bagi setiap mahluk untuk hidup dan beraktivitas setiap harinya. Dengan telah disusunnya dokumen SIPP (Strategi Induk Pembangunan Pertanian) 2015-2045 mengenai:

"Pertanian-Bioindustri Berkelanjutan Solusi Pembangunan Indonesia Masa Depan” oleh Kementerian Pertanian, sebagai awal pencanangan yang didasari kesadaran terhadap potensi dan urgensi pengembangan bioindustri, bioenergi dan bioekonomi berbasis pertanian, landasan strategis dalam pembangunan pertanian jangka panjang dan mainstreaming perspektif bioekonomi di Indonesia (Kementan, 2013). Untuk mengoptimalkan implementasinya, visi utama pembangunan pertanian yang berbasis pertanian bioindustri berkelanjutan dijabarkan dalam sembilan misi (Suswono, 2013), yaitu: (i) penataan ruang dan reforma agraria (RA); (ii) sistem pertanian tropika terpadu; (iii) kegiatan ekonomi produksi, informasi dan teknologi; (iv) pasca panen, agro-energi dan bioindustri berbasis pedesaan; (v) sistem pemasaran dan rantai nilai produk; (vi) sistem pembiayaan pertanian; (vii) sistem penelitian, inovasi dan sumberdaya manusia berkualitas; (viii) infrastruktur pertanian dan pedesaan; dan (ix) program legislasi, regulasi dan manajemen yang imperatif.

Terkait kebijakan SIPP tersebut, implementasi bioindustri untuk menghasilkan bioenergi melalui pengolahan kotoran ternak (sapi, kuda, kerbau, babi, dan unggas) sebagai bahan baku pembuatan biogas banyak di jumpai di seluruh wilayah Indonesia dan tersedia secara melimpah serta belum banyak di manfaatkan secara maksimal. Kotoran ternak sapi, babi, ayam dan limbah organik sisa-sisa tanaman merupakan sumber bahan baku yang baik untuk pembuatan biogas, dapat menggunakan salah satu bahan baku atau campuran keduanya. Jerami padi atau gergaji mengandung persentase karbon yang lebih tinggi dan dapat dicampur sebagai bahan untuk mendapatkan $\mathrm{C} / \mathrm{N}$ yang diinginkan sebagai bahan baku biogas. Penggunaan limbah pertanian sebagai bahan dasar biogas lebih membutuhkan waktu lama untuk proses hidrolis bahan selulosa dibandingkan kotoran ternak. Peran aktif dan keberpihakan berbagai 
kelembagaan sangat diharapkan sebagai dukungan penuh terhadap kemajuan petani dan pedesaan. Informasi dan bimbingan pembuatan biogas juga dapat diperoleh Badan Penyuluhan Pertanian, Penyuluh Pertanian dan aparat dinas terkait lainnya. Informasi yang patut diketahui sebelum membuat biogas selain untuk memenuhi kebutuhan rumah tangga, juga pemberdayaannya agar mampu menggerakkan usaha agribisnis yang menguntungkan.

Pemanfaatan biogas di Indonesia sebagai energi alternatif sangat memungkinkan untuk diterapkan di masyarakat terlebih seiring makin mahalnya harga bahan bakar minyak dan kadangkadang langka keberadaannya. Petani ternak dapat memulai pemanfaatan biogas dengan membuat unit produksi biogas yang sederhana, dan tidak membutuhkan biaya banyak dan lebih mudah dijalankan. Petani diberi pengarahan dan penyuluhan agar mampu menguasai pengaplikasian unit biogas secara mandiri. Selanjutnya petani ternak segera merasakan kebutuhan biogas yang lebih banyak, dan akan terdorong untuk membuat lebih banyak unit biogas dan memperbesar usahanya. Sekalipun demikian, di wilayah yang terlalu dingin (kurang dari $15^{\circ} \mathrm{C}$ ) dan terlalu panas (di atas $37^{\circ} \mathrm{C}$ ), terdapat sedikit masalah dalam memproduksi biogas, karena gas lebih bagus diproduksi pada suhu $32-37^{\circ} \mathrm{C}$.
Dengan pengunaan biogas sederhana, para petani ternak telah memanfaatkan limbah tanaman dan kotoran ternak serta dapat menghemat uang untuk pembelian bahan bakar. Pemberdayaan dan bimbingan pembuatan biogas dari penyuluh pertanian dan aparat terkait lainnya menjadi penting? agar mampu mengaplikasikan dan menggerakkan usaha bioindustri yang menguntungkan tersebut.

\section{PENGEMBANGAN MANAJEMEN BIOGAS POTENSI PEMASOK ENERGI BIOINDUSTRI}

Pemerintah hingga saat ini masih berkutat dalam masalah krusial penanggulangan tingkat kemiskinan dan meningkatnya pengangguran memiliki keterkaitan yang kuat dengan sektor lain terutama di masa kini, seperti: keterkaitan konsumsi, investasi, dan tenaga kerja. Titik lemah perekonomian Indonesia adalah tercermin pada belum optimalnya pemanfaatan berbagai sumberdaya alam termasuk limbahnya sebagai bahan baku yang mencerminkan belum optimalnya pergerakan di sektor riil. Kondisi tersebut berdampak pada terbatasnya kesempatan kerja dan berusaha. Ketangguhan sektor pertanian telah terbukti tidak banyak terpengaruh di beberapa masa krisis. Dikembangkannya, bioindustri sebagai industrialisasi pertanian, dimana bioindustri merupakan upaya/kinerja/proses usaha industri dalam: (i) menambah kapasitas untuk memperbesar volume produksi 
pertanian; (ii) meningkatkan dan mengembangkan produksi dan limbah hasil pertanian menjadi produk olahan yang lebih bernilai tambah dan beragam, berdayasaing, serta multi utility; dan (iii) dimaksudkan untuk mengubah paradigma dan pola pikir (mindset) bahwa sistem pertanian tidak hanya usahatani penghasil bahan konsumsi saja (Kasryno, 2013).

Efektivitas manajemen penanganan dan pengolahan limbah dan efisen dilakukan agar dapat meminimalisir dampak negatif dan memaksimalkan dampak yang menguntungkan dengan tetap memperhatikan keseimbangan antara sistem produksi dengan lingkungan hidup yang serasi dan lestari. Pengelolaan limbah yang tepat adalah sangat penting, karena: (a) bahan baku limbah dieksploitasi sebagai upaya untuk dapat mendatangkan keuntungan; serta (b) mencegah pencemaran di udara, tanah dan air. Biogas diproduksi oleh bakteri dari bahan organik dalam kondisi tanpa oksigen (anaerobic process) selama pengolahan atau proses fermentasi. Ketika limbah tanaman dan kotoran ternak disimpan bercampur air dalam tangki digester, limbah tanaman dan kotoran ternak mengalami pembusukan. Proses pencernaan anaerob yang merupakan dasar dan reaktor biogas yang diproses pemecahan bahan organik oleh aktivitas bakteri metanogenetik pada kondisi tanpa udara. Oleh karena itu, dibutuhkan implementasi: (i) penyusunan strategi pemasyarakatan pembuatan dan pemanfaatan biogas; (ii) penanganan bahan dasar, manajemen proses, dan pemilihan jenis mikroorganisme yang ikut aktif dalam proses pembentukan biogas (iii) pemahaman mengenai variabel-variabel yang mempengaruhi proses pembentukan biogas, komposisi gas, dan cara penanganan gas yang dihasilkan secara aman.

Tabel 1. Karakteristik Mikroorganisme Dalam Fermentasi Bahan Organik

Kelompok Mikroorganisme Nutrisi Mikroorganis

me

\begin{tabular}{lll}
\hline Hidrolitik & $\begin{array}{l}\text { Clostridium } \\
\text { thermocellum }\end{array}$ & Heterotroph \\
$\begin{array}{l}\text { H2 } \\
\text { Producing } \\
\text { Acetogen }\end{array}$ & S-isolate & Heterotroph \\
$\begin{array}{l}\text { Homoacetog } \\
\text { en }\end{array}$ & $\begin{array}{c}\text { Acetobacter } \\
\text { woodi }\end{array}$ & Micotroph \\
Methanogen & $\begin{array}{c}\text { 1. } \\
\text { Methanobacter }\end{array}$ & $\begin{array}{l}\text { Thermoautotr } \\
\text { opicum }\end{array}$ \\
& $\begin{array}{c}\text { 2. } \\
\text { Methanosarcina }\end{array}$ & barkeri \\
\hline
\end{tabular}

Sumber: Daru 2007; dalam: Elizabeth, 2016

Diperlukan pencegahan terhadap beberapa senyawa karena dapat menghambat proses penguraian dan fermentasi anaereob dalam pembuatan biogas (Thalib, 2008), seperti: (i) logam berat, seperti: Cadmium (Cd), Copper $(\mathrm{Cu})$, Chromium (Cr), dan beberapa ion logam berat bebas dalam kadar/kondisi melebihi persyaratan; (ii) antibiotik dan desinfektan. Biasa terjadi saat pembersihan kandang menggunakan desinfektan dan mengalir ke 
dalam unit pembuatan biogas bila tidak terpisah (berdekatan), dan jelas terlihat pengaruhnya terhadap proses pembentukan biogas bila kadarnya cukup tinggi. Seperti telah dikemukakan sebelumnya, biogas terbentuk pada suhu ideal sekitar $30^{\circ} \mathrm{C}$, menjadi kendala bila kurang dari $15^{\circ} \mathrm{C}$ dan di atas $37^{\circ} \mathrm{C}$, jika kandungan gas $\mathrm{CH} 4$ lebih dari 50\%, maka mudah terbakar, kandungan gas $\mathrm{CH} 4$ dalam biogas yang berasal dari kotoran ternak sapi kurang lebih 60\%. Kandungan metan dan gas lainnya dalam biogas yang dihasilkan tergantung jenis bahan baku yang digunakan, yang secara rinci dikemukakan pada Tabel 2.

Tabel 2. Komposisi Gas (\%) Dalam Biogas Dari Kotoran Ternak Dan Sisa Pertanian

\begin{tabular}{|c|c|c|}
\hline \multirow[t]{2}{*}{ Jenis gas } & \multirow[t]{2}{*}{$\begin{array}{l}\text { Kotoran } \\
\text { sapi }\end{array}$} & \multirow{2}{*}{$\begin{array}{l}\text { Campuran } \\
\text { kotoran } \\
\text { ternak } \\
\& \quad \text { sisa } \\
\text { pertanian }\end{array}$} \\
\hline & & \\
\hline Metana $\left(\mathrm{CH}_{4}\right)$ & 65,7 & $55-70$ \\
\hline $\begin{array}{l}\text { Karbondioksida } \\
\left(\mathrm{CO}_{2}\right)\end{array}$ & 27,0 & $27-45$ \\
\hline Nitrogen $\left(\mathrm{N}_{2}\right)$ & 2,3 & $9,5-3,0$ \\
\hline Karbonmonoksida & 0,0 & 0,1 \\
\hline Oksigen $\left(\mathrm{O}_{2}\right)$ & 0,1 & 6,0 \\
\hline Propane $\left(\mathrm{C}_{2} \mathrm{H}_{8}\right)$ & 0,7 & - \\
\hline $\begin{array}{l}\text { Hydrogen Sulfida } \\
\left(\mathrm{H}_{2} \mathrm{~S}\right)\end{array}$ & $\begin{array}{l}\text { Tidak } \\
\text { terukur }\end{array}$ & $\begin{array}{l}\text { Sedikit } \\
\text { sekali }\end{array}$ \\
\hline $\begin{array}{l}\text { Nilai kalor (kkn } \\
\left.1 / \mathrm{m}^{2}\right)\end{array}$ & 6513 & $400-6700$ \\
\hline
\end{tabular}

Biogas digunakan untuk berbagai keperluan, seperti: (i) Bahan bakar untuk memasak, pengeringan, penerangan, atau pekerjaan-pekerjaan lain yang memerlukan pemanasan. Dibutuhkan peralatan yang didisain sehingga efisiensi pembakarannya tinggi; (ii) Sebagai bahan bakar penggerak motor (terutama motor stationer). Untuk keperluan ini, biogas sebelumnya harus dibersihkan dari kemungkinan adanya gas $\mathrm{H}_{2} \mathrm{~S}$ yang dapat menjadi penyebab korosi. Sementara itu, kelebihan biogas terkait kandungan, nilai kalorinya dikemukakan pada Tabel 3.

Tabel 3. Perbandingan Kandungan, Nilai Kalori Biogas, Gas dari Sumber Energi Lain

\begin{tabular}{lllll}
\hline $\begin{array}{l}\text { Kandungan } \\
(\%) \text { dan } \\
\text { Nilai Kalori }\end{array}$ & $\begin{array}{l}\text { Gas } \\
\text { Alam }\end{array}$ & $\begin{array}{l}\text { Bioga } \\
\text { s }\end{array}$ & $\begin{array}{l}\text { Coalg } \\
\text { as }\end{array}$ & $\begin{array}{l}\text { Waterg } \\
\text { as }\end{array}$ \\
\hline Metan & 97,0 & 54,7 & 31,6 & 0,7 \\
$\begin{array}{l}\text { Karbon } \\
\text { Dioksida }\end{array}$ & 0,8 & 27,4 & 1,8 & 3,5 \\
$\begin{array}{l}\text { Karbon } \\
\text { Monoksida }\end{array}$ & - & 0,1 & 6,3 & 43,5 \\
\hline $\begin{array}{l}\text { Hidrogen } \\
\text { Nitrogen }\end{array}$ & - & 1,1 & 53,0 & 47,3 \\
\hline $\begin{array}{l}\text { Oksigen } \\
\text { Nilai Kalori }\end{array}$ & - & 1,5 & 3,4 & 4,4 \\
\hline Kcal/m ${ }^{3}$ ) & & 5,7 & 0,2 & 0,6 \\
\hline
\end{tabular}

Sumber: Daru, 2007. dalam: Elizabeth, 2017.

Dengan mencermati Tabel 3, diketahui bahwa biogas memiliki keunggulan tingkat nilai kalorinya dibanding beberapa sumber energi lainnya (coalgas dan watergas). Setiap $\mathrm{m}^{3}$ biogas setara dengan 0,5 $\mathrm{kg}$ gas alam cair (liquid petroleum gases = $L P G$ ), 0,54 liter bensin, 0,52 liter minyak diesel, dan dapat membangkitkan tenaga listrik sebesar 1,25 - 1,50 kilo watt hour (kwh).

Biogas, selain sebagai bahan bakar renewable bioenergy terbarukan yang ramah 
lingkungan karena tidak mengeluarkan asap, hasil sampingan dari pembuatan biogas adalah sludge, berupa pupuk organik (biofertilizer) yang dapat dimanfaatkan sebagai pupuk karena kaya unsur hara, sehingga selain biogas, juga dihasilkan sludge dan effluent. Kelebihannya adalah pupuk sludge tersebut tidak lagi mengundang parasit dan biji gulma yang dapat tumbuh, sehingga tidak ada unsur ikutan yang berbahaya di dalamnya. Jika digunakan sendiri, jangan tempatkan pupuk tersebut hanya pada satu tempat, melainkan disebar tipis-tipis dan merata ke seluruh areal pertanaman yang pada akhirnya menyuburkan tanaman. Pupuk organik tersebut dapat menjadi produk agribisnis yang menguntungkan.

Pencemaran logam berat di lahan usahatani terkait dengan pelaksanaan pengembangan pertanian intensif (disamping industrialisasi dan urbanisasi), sehingga lambat laun lahan pertanian terkontaminasi oleh logam berat dan polutan pengaplikasian (penetrasi) zat anorganik (kimia). Pencemaran tanah pertanian oleh logam berat mengakibatkan produk pertanian pangan mengandung logam berat melebihi persyaratan yang menimbulkan resiko tinggi bagi kesehatan konsumen. Pupuk dari sludge hasil ikutan biogas, bertujuan dan diharapkan menjadi solusi alternatif pencegahan pencemaran logam berat pada tanah. Kemungkinan pemanfaatan bahan-bahan tersebut masih terbuka luas, dimana dari hasil penelitian diketahui bahwa dalam sludge ini ditemukan vitamin $\mathrm{B}_{12}$ yang cukup banyak, mencapai 3.000 mikro gram vitamin $\mathrm{B}_{12}$ per $\mathrm{kg}$ sludge kering. Sebagai perbandingan, tepung ikan dalam ransum makanan ternak hanya mengandung 200 mikro gram per $\mathrm{kg}$ dan tepung tulang sekitar 100 mikro gram per $\mathrm{kg}$ (Wibowo, Daru, dalam: Elizabeth, 2016). Kenyataan ini membuktikan terbukanya peluang untuk pemanfaatan sludge dalam sistem biogas menjadi makanan ternak. Pemanfaatan limbah kotoran ternak menjadi sumber bahan baku biogas, diharapkan dapat menjadi salah satu solusi alternatif pencegahan pencemaran logam berat pada tanah pertanian.

\section{PEMBERDAYAAN EKONOMI DAN SOSIAL PENGGUNAAN BIOGAS}

Di era globalisasi ini, pembuatan biogas kembali digalakkan di seluruh Nusantara, seperti di pulau Jawa, yang didasari menurunnya ketersediaan bahan bakar minyak, mengurangi emisi gas metana, dan menghasilkan pupuk organik (Junaedi, 2012. Indrawati, 2015). Teknologi menurunkan gas metana pada komoditas peternakan masih perlu diinventarisir dan diseleksi agar sesuai dan dapat diterapkan terutama pada peternakan rakyat. Berbagai upaya yang ditempuh selain dapat menurunkan emisi gas metana dapat pula meningkatkan produktivitas ternak (Abdullah et al, 2008. dalam: Elizabeth, 
2017). Dalam kegiatan menurunkan emisi gas rumah kaca khususnya gas metana pada ternak rakyat, perlu dikembangkan aspek kelembagaan (dalam hal ini kepemilikan ternak). Sebagian besar peternak rakyat hanya memiliki sekitar 2 ekor sapi/RT dan dengan pakan hijauan saja (Suharto, 2010), sehingga sulit mengaplikasikan pakan konsentrat rendah emisi.

Inovasi teknologi pada hakekatnya bertujuan meningkatkan kesejahteraan, tetapi dapat pula membawa bencana apalagi tidak dikaji secara bijak terhadap kemungkinan dan dampak merugikan yang akan timbul di masa datang, sebagai akibat/efek dari teknologi yang ada saat ini. Untuk itu, perlu dikembangkan biogas menjadi pasar karbon yang dapat memberikan insentif kepada peternak kecil. Strategi penurunan emisi gas metana pada komoditas ternak dapat dilakukan pendekatan sumber energi gas metana yaitu gas metana enteric dan manura (kotoran). Kotoran ternak disimpan dalam kondisi anaerob (temperatur $15^{\circ} \mathrm{C}$ ) maka bakteri metanogenik memproduksi gas metana (Supriadi et al, 2009). Pengolahan kotoran ternak dengan teknik pemanfaatan energi metana dalam bentuk biogas, dapat menurunkan $70 \%$ emisi metana ke atmosfer. Hasil akhir berupa padatan yang berfungsi sebagai pupuk organik tanaman. Satu kg kotoran ternak melepaskan sekitar 208-268 liter gas metana ke atmosfer.
Ransum ternak yang bergizi tinggi, menghasilkan kotoran berkadar metana rendah.

Penting dan mahalnya kesehatan saat ini membuat berbagai pihak yang bergerak di bidang pertanian, giat merintis pertanian organik, yaitu usahatani yang bersifat alami, yang mayoritas menggunakan sarana produksi berbasis bahan organik, seperti: pupuk organik, racun dan obat-obatan organik untuk usahatani. Meskipun belum $100 \%$ terlepas dari penggunaan saprodi anorganik, namun berbagai pihak tersebut sudah berusaha untuk menyeimbangkan penggunaannya untuk tujuan kesehatan, lingkungan, dan pertumbuhan, baik fisik maupun kimiawinya. Produksi biogas dari kotoran ternak dimaksudkan untuk mendapatkan nilai tambah dari pemanfaatannya sebagai alternatif dan substitusi bahan bakar yang efisiensi. Teknologi biogas yang di introduksikan terdiri atas kala rumah tangga sampai skala industri, menggunakan peralatan biaya yang murah (kantong plastik) sampai konstruksi semen beton.

Penanganan limbah usahatani-ternak dengan sistem fermentasi anaerobik menggunakan reaktor biogas memiliki beberapa keuntungan seperti: dapat mengurangi emisi gas rumah kaca, mengurangi bau yang tidak sedap, mencegah penyebaran penyakit, menghasilkan pupuk dan energi. 
Pemanfaatan limbah seperti ini secara ekonomi sangat kompetitif seiring naiknya harga bahan bakar minyak dan pupuk anorganik. Sasaran pengembangan teknologi biogas untuk menangani limbah agroindustri diharapkan dapat memberikan nilai tambah ekonomi dan perbaikan lingkungan hidup, seperti yang dikemukakan pada Tabel 4 dan kelayakan ekonomi yang hasil analisisnya dikemukakan pada Tabel 5 .

Tabel 4. Biaya, Produksi Gas, Pendapatan dan Keuntungan

\begin{tabular}{lll}
\hline Uraian & Generator Listrik & Reaktor Biogas \\
\hline -Biaya investasi (Rp) & 10.500 .000 & 8.800 .000 \\
-Biaya operasional \& perawatan (Rp/tahun) & 2.375 .000 & 975.000 \\
-Umur ekonomi (tahun) & 5 & 15 \\
-Produksi gas, m3/hari & - & 7 \\
-Produksi gas, m3/tahun & 12 & 2.555 \\
-Suku Bunga, \%/tahun & 9 & 9 \\
-Pendapatan, Rp/tahun & 9.535 .600 & 9.250 .800 \\
-Keuntungan, Rp/tahun & 5.065 .600 & 5.000 .330 \\
\hline
\end{tabular}

Sumber: Elizabeth, 2017.

Tabel 5. Hasil Analisis Kelayakan Ekonomi

\begin{tabular}{lll}
\hline Uraian & Generator Listrik & Reaktor Biogas \\
\hline Net Present Worth (NPW), Rp & 15.985 .345 & 21.789 .355 \\
Net Present Cost (NPC), Rp & 20.585 .775 & 21.175 .385 \\
Net Present Revenue (NPR), Rp & 28.868 .645 & 42.073 .320 \\
B/C Ratio & 1,98 & 1,41 \\
Simple Payback, tahun & 1,84 & 3,76 \\
Internal Rate Return (IRR), \% & 41,93 & 21,67 \\
\hline
\end{tabular}

Sumber: Elizabeth, 2017.

Dari hasil analisis kelayakan ekonomi, dengan nilai $\mathrm{B} / \mathrm{C}$ ratio lebih dari 1 , maka usaha tersebut dinyatakan layak untuk dilakukan. Secara sederhana efisiensi dan nilai ekonomi dari penggunaan biogas sebagai substitusi bahan bakar gas yang umum dipergunakan adalah sebagai berikut: bila satu tabung gas alam (LPG) berisi bersih (netto) $12 \mathrm{~kg}$ dengan harga jual (HET) sekitar Rp. 145.000,- hingga Rp.
155.000,- dapat dipergunakan selama satu bulan oleh satu keluarga, maka biaya yang dikeluarkan sekitar Rp. 4.800,- hingga Rp. 5.200,-. Bila bahan bakar yang dipergunakan adalah minyak tanah sebanyak 1 - 2 liter per hari dengan harga Rp. 9.000,- per liter, selama sebulan biaya minyak tanah sekitar Rp 500.000,- - Rp. 540.000,- maka akan menghemat sekitar Rp. 11.500,- hingga Rp.13.500,- per hari. Suatu efisiensi 
pengeluaran uang dari perbedaan nilai biaya rumah tangga yang relatif cukup besar untuk di pedesaan, terlebih bila hanya untuk membeli bahan bakar saja, di luar biaya kebutuhan hidup sehari-hari lainnya.

Terkait dengan masyarakat sebagai pemberdayaan kelembagaan pelaku berbagai ragam usaha, terutama pelaku usahatani (petani), pelaku bioindustri, peran dan makna partisipasi (dalam berbagai program pembangunan dan kebijakan pemerintah) merupakan proses dan keadaan (situasi) dimana seluruh pihak (terutama yang terkait/berhubungan, langsung/ tidak langsung) dapat membentuk/membangun kondisi dan ikut serta terlibat serta kooperatif dalam seluruh inisiatif, tahapan dan aktivitas pembangunan. Dalam pemberdayaan kelembagaan dan partisipasi, siapapun dapat berperan aktif, baik berperan dalam bermasyarakat, dalam kehidupan sendiri, terlebih lagi keterlibatan untuk berperan dalam pembangunan. Meski memiliki makna yang berbeda-beda (tergantung pada "apa" dan "bagaimana" mereka turut serta terlibat), namun pada akhirnya partisipasi bertujuan untuk increasing self-determination (meningkatkan kemandirian/keteguhan diri), serta terkontruksinya/terbangunnya kontrol (build construction control) dan inisiatif masyarakat terhadap pengelolaan sumberdaya untuk pembangunan.
Sementara itu, sebagai pegangan, pemantau dan pengawal dalam terlaksana dan suksesnya suatu program pembangunan, diperlukan partisipasi dalam monitoring dan evaluasi (participatory monitoring and evaluation = PM\&E); yang berupaya melibatkan (to engage) pihak-pihak stakeholders utama untuk lebih aktif dalam merefleksikan dan mengukur (assesing) kemajuan proyek dan terutama pencapaian hasil. Untuk itu, pelaksanaan program pembangunan hendaknya tetap menjalankan prinsip utama PM\&E, yaitu: 1) stakeholders utama adalah partisipan yang aktif tidak hanya sebagai sumber informasi; 2) membangun dan mengembangkan kemampuan masyarakat setempat untuk menganalisa, merefleksikan dan berperan aktif/mengambil bagian; 3) terjadinya proses belajar bersama (joint learning) dari seluruh stakeholders pada berbagai level; dan 4) adanya komitmen untuk terciptanya proses yang lebih tepat dan multi guna. Dengan demikian, dasar terpenting dibutuhkannya partisipasi adalah agar terjaminnya pembangunan bioindustri berkelanjutan karena sangat tergantung pada social process dan terkait dengan tiga aspek utama masyarakat (sosial, ekonomi dan lingkungan) tersebut di atas. Hal tersebut juga membuat penduduk pedesaan berangsur-angsur bisa melepaskan diri dari jebakan paradox of plenty (kondisi dimana 
suatu negara yang kaya sumberdaya alam tetapi rakyatnya miskin) (Fauzi, 2014).

Demikian juga halnya bila dikaji dari aspek keberlanjutan, pengusahaan biogas yang sudah cukup baik dan tidak memiliki dampak negatif, namun masih relatif kurang dari sisi pemasaran dan distribusi energi biogas sebagai subsistem aktivitas bisnis dari produk hasil suatu usaha, diarahkan pada perbaikan mekanisme berbagai pendekatan yang umum berlaku dalam aktivitas suatu usaha pengolahan (Elizabeth, 2018a). Kelompok tani ternak merupakan salah satu wadah berbentuk kelembagaan yang memiliki peran penting di pedesaan. Lembaga di pedesaan lahir untuk memenuhi kebutuhan sosial masyarakatnya (Elizabeth, 2014). Sifatnya tidak linier, namun cenderung merupakan kebutuhan individu anggotanya, antara lain berupa kebutuhan: fisik, rasa aman (savety), hubungan sosial (social affiliation), pengakuan (esteem), pengembangan pengakuan (self actualization).

Pendukung utama terlaksananya upaya pencapaian pengembangan pengusahaan dan penggunaan biogas, sangat diperlukan ketersediaan perangkat kebijakan yang memadai, teknologi dan informasi yang dibutuhkan, serta berfungsinya lembaga pendukung lainnya seperti: penyuluhan, pemasaran, dan sistem pendekatan instansi terkait (Elizabeth, 2008). Lemahnya kinerja lembaga penyuluhan di pedesaan salah satunya dapat mengakibatkan informasi harga umumnya hanya diperoleh dari sesama petani, pedagang, pasar, dan media massa (Elizabeth, 2017a). Kondisi tersebut mengindikasikan diperlukan penanganan, pembinaan dan sosialisasi manfaat dan multi fungsi keuntungan pengusahaan dan penggunaan biogas. Oleh karena itu diperlukan peran aktif dan keberpihakan semua pihak terkait, dengan kontinuitas pengarahan, bimbingan, dan sosialisasi dari pihak penyuluh lapang terhadap petani peternak akan manfaat dan multi fungsi serta keuntungan pengusahaan dan penggunaan biogas (Elizabeth, 2016).

\section{METODOLOGI}

Tulisan ini merupakan pembaharuan (up dating) dari beberapa tulisan terkait sebelumnya yang oleh penulis kembali direfer karena pentingnya informasi yang terdapat dalam beberapa tulisan sebelumnya tersebut. Pemaparannya diupayakan semaksimal mungkin terutama untuk meminimalisir kesan penduplikasiaan serta mengutamakan kekinian data. Secara umum, dengan metode deskriptif kualitatif tulisan ini mengemukakan secara komprehensip berbagai hasil analisis data sekunder dan data primer yang diperoleh dari lapang (provinsi Riau dan Sumatera Selatan, 2017), me-review berbagai tulisan terkait dan menganalisis berbagai implementasi pembuatan biogas, efisiensi 
serta efektivitas pemanfaatannya. Untuk mengkaji kelayakan ekonomi, digunakan metode Net Present Worth (NPW), Net Present Cost (NPC), Net Present Revenue (NPR), B/C Ratio, dan Internal Rate Return (IRR).

Proses terbentuknya material bahan bakar yang berasal dari fosil membutuhkan waktu yang sangat lama, dan semakin menipisnya cadangan minyak bumi mengharuskan manusia untuk segera melakukan berbagai tindakan untuk menghasilkan bahan bakar terbarukan dan ramah lingkungan, sebagai substitusi bahan bakar dan sumber energi. Turut dikemukakan dua teknologi umum untuk memperoleh biogas, yaitu: (i) proses fermentasi kotoran ternak memakai digester yang didesain khusus dalam kondisi anaerob; (ii) dikembangkannya teori menangkap (menampung) gas metan dari lokasi tumpukan pembuangan sampah tanpa harus membuat digester khusus (Tuti, 2006. dalam: Elizabeth, 2017). Gas dari hasil digester biogas, digunakan terutama sebagai bahan bakar memasak, penerangan, pupuk organik, dan keperluan lain. Kuantitas produksi biogas kotoran ternak dipengaruhi dan ditentukan oleh kapasitas, jenis dan kontruksi reactor (digester, fixed dome dan floating dome). Peternak di Jawa kebanyakan menggunakan fixed dome (Abdullah et al, 2008. dalam: Elizabeth, 2017).

Untuk teknik digester, diperlukan minimal 3 buah cincin gorong- gorong/septik tank untuk tangki digester (pencerna), sebuah drum besar penampung gas methane (biogas) yang mampu memuat sekitar 200 liter kotoran ternak dan air. Pipa logam diameter $2 \mathrm{~cm}$, untuk saluran pengeluaran gas dan satu kran pengeluaran biogas, paralon berdiameter $2 \mathrm{~cm}$ sebagai saluran gas dari tangki pencerna (digester) ke kompor untuk memasak, lampu gas dan lainnya. Seluruh unit produksi biogas ditanam dan diletakkan minimal 10 meter terpisah di luar rumah dan sumber air, agar tidak mencemari saat memasukkan bahan baku biogas. Dua bulan sebelum membuat unit biogas dibuat "biang" pemicu (starter) pembentukan gas, dengan mencampur aduk rata 2 liter kotoran ternak (sapi, babi, ayam atau kuda) dan 2 liter air seperti pasta di wadah terbuka. Biang pembentuk gas harus tetap hangat, diaduk tiap dua hari sekali selama dua bulan untuk wilayah berkelembaban rendah.

Biang diperlukan sebagai pemicu untuk mempercepat pembentukan gas dalam unit biogas. Campurkan kotoran ternak dan limbah tanaman yang sudah diberi air (komposisi 1:1), diaduk sampai seperti pasta agar mempercepat terbentuknya gas (dapat ditambahkan kapur untuk menetralkan $\mathrm{pH}$ ). Diperlukan waktu kira-kira 2 sampai 4 minggu (tergantung bahan baku dan kondisi lingkungan), untuk memulai pembentukan gas dari campuran bahan organik tersebut. Pembentukan gas 
sekitar 8 minggu, separuhnya terbentuk pada 2 sampai 4 minggu pertama dan separuh berikutnya pada minggu ke-4 sampai ke-8, serta berhenti sama sekali pada minggu ke-9.

Telah terbentuknya gas dapat diketahui beberapa hari setelah drum penangkap biogas terangkat ke atas. Keluarkan udara yang terbentuk dengan membuka kran dan menekan drum sampai ke dasar tangki digester. Hindari adanya api di sekitar unit produksi biogas dan tidak diperbolehkan membakar gas yang pertama terbentuk karena mengandung udara di dalamnya dan dapat meledak. Selanjutnya tutup kran menghindari terbentuk udara dalam gas dan unit biogas bekerja kembali mengumpulkan gas, dan sudah bisa digunakan untuk memasak. Dengan mengatur perimbangan gas-udara yang tepat, maka biogas terbakar dengan baik, yang ditandai nyala api berwarna biru dan tidak tersumbat arang pembakaran (nyala berwarna kuning). Pembersihan dilakukan dengan mencuci menggunakan air dan sabun. Untuk siklus selanjutnya, kosongkan limbah organik dan sisakan kira-kira 4 liter bahan organik tersebut untuk digunakan kembali sebagai biang/starter pembentukan gas berikutnya dan proses selanjutnya.

\section{ANALISIS DAN ALTERNATIF SOLUSI/PENANGANAN}

Dengan adanya biogas, maka petani merasakan berkurangnya pengeluaran untuk biaya bahan bakar (minyak tanah, gas komersial di pasaran, arang dan kayu bakar) sehari-hari. Selain itu, dengan penggunaan biogas, maka efisiensi waktu untuk memasak oleh anggota rumah tangga petani dapat digunakan untuk bekerja selain di sawah, kebun maupun usaha kerajinan tangan tingkat rumah tangga. Beberapa keuntungan/nilai tambah terkait lainnya bila menggunakan anaerobik, seperti: 1) keuntungan pengolahan digester, yaitu: digester anaerob merupakan proses pengolahan limbah yang alami; membutuhkan lahan lebih kecil dibanding proses kompos aerobik atau penumpukan sampah; memperkecil volume atau berat limbah yang dibuang; memperkecil rembesan poluton. 2) Keuntungan Energi, yaitu: proses energi lebih bersih; memperoleh bahan bakar berkualitas tinggi dapat diperbaharui; biogas dapat dimanfaatkan untuk berbagai penggunaan. 3) Keuntungan Lingkungan, yaitu: menurunkan emisi gas metan dan karbon dioksida secara signifikan; menghilangkan bau; memperkecil udara keluar dari sampah; menghasilkan kompos yang bersih dan pupuk kaya nutrisi; memaksimalkan proses daur ulang limbah yang sudah terbuang; menghilangkan bakteri coliform hingga 90\% (memperkecil kontaminasi sumber air yang sudah ada). 4) Keuntungan Sosial dan Ekonomi, yaitu: penggunaan kotoran ternak sebagai biogas sumber energi RT dan pupuk 
tanaman, tentu mengefisienkan pengeluaran rumah tangga petani dan peternak; lebih ekonomis dibandingkan siklus ulang proses pembuatan limbah pertanian;

Solusi dari aspek ekonomi terdampak kajian kondisi sosialnya, bila seekor sapi potong dewasa mampu menghasilkan/ mengeluarkan kotoran sekitar 10\% dari berat badannya per hari dengan kisaran harga Rp500000-Rp. 1000 000,-/ton (Ilham et al, 2011. Elizabeth, 2017. Ilham et al, 2018), maka secara sederhana dapat diperkirakan besarnya sumber bahan baku biogas dan pupuk yang diperoleh petani dan peternak. Serta besarnya pengefisienan pengeluaran untuk biaya bahan bakar gas dan pupuk dengan mensubstitusikannya dengan kotoran sapi peliharaan tersebut. Sementara itu dari beberapa hasil penelitian diperoleh gambaran skala usaha yang dinilai dapat menguntungkan adalah pemeliharaan sekitar 3- 4 ekor sapi per rumah tangga.

Dari aspek pemberdayaan sosial kelembagaan adalah terjalinnya sifat sosial dalam kebersamaan dan tenggang rasa antar masyarakat pengguna biogas metan (umumnya terdiri antar kelompok untuk satu sumur/sumber). Sifat kebersamaan, rasa saling memiliki, saling berbagi, serta saling merawat agar sumber biogas kelompok tetap berfungsi baik, yang menunjukkan berfungsinya aktivitas kelembagaan suatu kelompok masyarakat.
Petani pemilik ternak maupun yang tidak/belum, memperoleh pupuk kandang dari sekitarnya. Terjalinnya hubungan aktif antar kelembagaan di hulu (di perdesaan/produsen) hingga hilir (pengguna/konsumen). Kelompok petani dan peternak saling bertukar informasi berkaitan teknologi budidaya, pemasaran, dan lainnya yang sangat dibutuhkan dalam pengembangan usaha tani dan ternak (Elizabeth, 2017).

Terkait dengan masyarakat sebagai pemberdayaan kelembagaan pelaku berbagai ragam usaha, terutama pelaku usahatani (petani), pelaku bioindustri, peran dan makna partisipasi (dalam berbagai program pembangunan dan kebijakan pemerintah) merupakan proses dan keadaan (situasi) dimana seluruh pihak (terutama yang terkait/berhubungan, langsung/ tidak langsung) dapat membentuk/membangun kondisi dan ikut serta terlibat serta kooperatif dalam seluruh inisiatif, tahapan dan aktivitas pembangunan. Dalam pemberdayaan kelembagaan dan partisipasi, siapapun dapat berperan aktif, baik berperan dalam bermasyarakat, dalam kehidupan sendiri, terlebih lagi keterlibatan untuk berperan dalam pembangunan. Meski memiliki makna yang berbeda-beda (tergantung pada "apa" dan "bagaimana" mereka turut serta terlibat), namun pada akhirnya partisipasi bertujuan untuk increasing self-determination (meningkatkan 
kemandirian/keteguhan diri), serta terkontruksinya/terbangunnya kontrol (build construction control) dan inisiatif masyarakat terhadap pengelolaan sumberdaya untuk pembangunan.

Sementara itu, sebagai pegangan, pemantau dan pengawal dalam terlaksana dan suksesnya suatu program pembangunan, diperlukan partisipasi dalam monitoring dan evaluasi (participatory monitoring and evaluation = PM\&E); yang berupaya melibatkan (to engage) pihak-pihak stakeholders utama untuk lebih aktif dalam merefleksikan dan mengukur (assesing) kemajuan proyek dan terutama pencapaian hasil. Untuk itu, pelaksanaan program pembangunan hendaknya tetap menjalankan prinsip utama PM\&E, yaitu: 1) stakeholders utama adalah partisipan yang aktif tidak hanya sebagai sumber informasi; 2) membangun dan mengembangkan kemampuan masyarakat setempat untuk menganalisa, merefleksikan dan berperan aktif/mengambil bagian; 3) terjadinya proses belajar bersama (joint learning) dari seluruh stakeholders pada berbagai level; dan 4) adanya komitmen untuk terciptanya proses yang lebih tepat dan multi guna. Dengan demikian, dasar terpenting dibutuhkannya partisipasi adalah agar terjaminnya pembangunan bioindustri berkelanjutan karena sangat tergantung pada social process dan terkait dengan tiga aspek utama masyarakat (sosial, ekonomi dan lingkungan) tersebut di atas. $\mathrm{Hal}$ tersebut juga membuat penduduk pedesaan berangsur-angsur bisa melepaskan diri dari jebakan paradox of plenty (kondisi dimana suatu negara yang kaya sumberdaya alam tetapi rakyatnya miskin) (Fauzi, 2014).

Demikian juga halnya bila dikaji dari aspek keberlanjutan, pengusahaan biogas yang sudah cukup baik dan tidak memiliki dampak negatif, namun masih relatif kurang dari sisi pemasaran dan distribusi energi biogas sebagai subsistem aktivitas bisnis dari produk hasil suatu usaha, diarahkan pada perbaikan mekanisme berbagai pendekatan yang umum berlaku dalam aktivitas suatu usaha pengolahan (Elizabeth. 2018a). Kelompok tani ternak merupakan salah satu wadah berbentuk kelembagaan yang memiliki peran penting di pedesaan. Lembaga di pedesaan lahir untuk memenuhi kebutuhan sosial masyarakatnya (Elizabeth, 2014). Sifatnya tidak linier, namun cenderung merupakan kebutuhan individu anggotanya, antara lain berupa kebutuhan: fisik, rasa aman (savety), hubungan sosial (social affiliation), pengakuan (esteem), pengembangan pengakuan (self actualization).

Pendukung utama terlaksananya upaya pencapaian pengembangan pengusahaan dan penggunaan biogas, sangat diperlukan ketersediaan perangkat kebijakan yang memadai, teknologi dan informasi yang dibutuhkan, serta berfungsinya lembaga pendukung lainnya 
seperti: penyuluhan, pemasaran, dan sistem pendekatan instansi terkait (Elizabeth, 2008). Lemahnya kinerja lembaga penyuluhan di perdesaan salah satunya dapat mengakibatkan informasi harga umumnya hanya diperoleh dari sesama petani, pedagang, pasar, dan media massa (Elizabeth, 2017a). Kondisi tersebut mengindikasikan diperlukan penanganan, pembinaan dan sosialisasi manfaat dan multi fungsi keuntungan pengusahaan dan penggunaan biogas.

Oleh karena itu diperlukan peran aktif dan keberpihakan semua pihak terkait, dengan kontiniutas pengarahan, bimbingan, dan sosialisasi dari pihak penyuluh lapang terhadap petani peternak akan manfaat dan multi fungsi serta keuntungan pengusahaan dan penggunaan biogas (Elizabeth, 2016). Dengan demikian, terkait tantangan tersebut, pembuatan biogas merupakan diversifikasi upaya dan solusi untuk memperoleh energi dari sumber-sumber energi lain dapat dianggap sebagai energi pengganti minyak dan gas bumi, disebut sebagai energi alternatif bahan pengganti minyak bumi.

\section{REFERENSI}

Abdullah, M.A.A., Thalib, Y.T., Anggraeni, Mariyono. 2008. Teknologi Peternakan Sapi Potong Berwawasan Lingkungan. Puslitbang Peternakan. Buletin Ilmu Peternakan Indonesia- Wartazoa Vol. 10 No. 3. 2008, hal. 149-156.

Badan Penelitian dan Pengembangan Pertanian. 2005. Prospek dan Arah
Pengembangan Agribisnis:

Rangkuman Kebutuhan Investasi.

Badan Penelitian dan

Pengembangan Pertanian

Kementerian Pertanian.

Balai Besar Industri Agro Bogor (BBIA. Bogor). 2014. Pengembangan Industri Agro di Indonesia. Makalah disampaikan pada Seminar Forum Komunikasi Kelitbangan (FKK) Kementan. Serpong. 14 Mei 2014.

Daru, M. 2007. Pemanfaatan Kotoran Ternak dan Peningkatan Sanitasi Sumber Energi Alternatif dan penimngkatan Sanitasi Lingkungan. Saat ini bekerja sebagai Peneliti Madya di Direktorat Teknologi Agroindustri dan Bioteknologi. Jurnal Teknologi Lingkungan, Vol.1, No. 1, Januari 2007: 27-32. bttp/wmw/blogs/energy/tanggal, 16 November 2018.

Elizabeth, R. 2018. Akselerasi Agroindustri dan Nilai Tambah: Faktor Pendukung Pencapaian Dayasaing Produk Dan Percepatan Pembangunan Pertanian Di Indonesia. OJS. Online Jurnal System. Universitas Ekasakti. Padang. Sumatera Barat.

Elizabeth, R. 2018a. PERTANIAN BIOINDUSTRI. Solusi Pertanian Masa Depan. Buku. Bunga Rampai. Badan Litbang Pertanian. Kementerian Pertanian. Jakarta. IAARD PRESS ISBN 978-602-695426-8

Elizabeth, R. 2017. Revitalisasi Industri Produk Olahan dan Pemberdayaan Lembaga Kemitraan Mendukung Peningkatan Pemasaran, Daya Saing Dan Pensejahteraan Petani Pisang. Journal of Agricultural Scienties. Universitas Ekasakti. Padang Sumatera Barat. Volume 2. Issue 1. June 2017. ISSN Cetak: 2528-5556. ISSN Online: 2528-6226.

Elizabeth, R. 2017a. Akselerasi Pemberdayaan dan Peningkatan 
Kompetensi Dalam Sistem Produksi Untuk Mengatasi Permasalahan Ekonomi di Indonesia. Volume 2. Issue 1. June 2017. ISSN Cetak: 2528-5556. ISSN Online: 2528-6226.

Elizabeth, R. 2016. Pemberdayaan Petani Dalam Pengelolaan Tanaman Dan Ternak Guna Meningkatkan Kesejahteraan Petani. Prosiding Seminar Nasional Agustus 2016. BPTP Sulawesi Utara. Manado. Badan Litbang Pertanian. Sekretaris Jenderal Pertanian. Kementerian Pertanian.

Elizabeth, R. 2015. Pencapaian Daya Saing Melalui Peningkatan Teknologi Pengolahan, Peningkatan Kelembagaan dan Pemasaran Produk Pangan Olahan. PERHEPI. Tema: Indonesia Menuju Swasembada Pangan dalam Tiga Tahun Kedepan: "Tinjauan Konseptual, Teoritis dan Empiris". Kendari, 9 Maret, 2015.

Elizabeth, R. 2014. Mewujudkan Kemandirian dan Ketahanan Pangan Melalui Revitalisasi dan Pengembangan Infrastruktur Pertanian. Konferensi Nasional XVII dan Kongres XVI PERHEPI. IPB International Convention Center (IICC). Bogor. 28-29 Agustus 2014.

Elizabeth, R. 2008. Diagnosa Kemarjinalan Kelembagaan Lokal untuk Menunjang Perekonomian Rakyat di Pedesaan. Jurnal SOCA. Vol. 8. No. 2. Juli 2008. hal. 58-64. Jurnal Sosial Ekonomi Pertanian. Universitas Udayana. Bali.

Fauzi, A. 2014. Hilirisasi Cermin Politik Industri. Bisnis Indonesia. http://www.neraca.co.id/ bisnisindonesia. (download 28 Oktober 2018).

Hambali, E. 2014. Peran Pertanian dalam Membantu Mewujudkan Kemandirian Energi. Semnas Hari
Pangan Sedunia (HPS) ke 34. Makassar, 4 November 2014. Pusat Sosial Ekonomi dan Kebijakan Pertanian (PSEKP). Bogor. Kementerian Pertanian. Jakarta.

Hambali, E., Marbun B.T.H., M. Rivai. 2014. Esterifikasi Gliserol Hasil Samping Industri Biodiesel Olein Sawit sebagai Water-Based Mud. Buku Penelitian Unggulan. IPB Press.

Harahap, F.M., Apandi. S, Ginting. 1978. Teknolohi Gasbio Pusat Teknologi Pembangunan Institut Teknologi Bandung.

Haryono. 2014. Ketersediaan Teknologi Siap Guna Dalam Pengembangan Sistem Pertanian Bioindustri Berbasis Pangan Lokal Potensial. Semnas Hari Pangan Sedunia (HPS) ke 34. Makassar, 4 November 2014. Pusat Sosial Ekonomi dan Kebijakan Pertanian (PSEKP). Bogor. Kementerian Pertanian. Jakarta.

Indrawati, S. 2015. Pembangkitan Biogas dari Kotoran Sapi: Hidrolisis Termal Pada Tahap Pengolahan Pendahuluan, Jurnal Teknik Kimia, Institut Teknologi Sepuluh Nopember. Surabaya.

Ilham, N., E. Basuno, W.K. Sejati., Elizabeth, R., F.B.M Dabukke, S. Nuryati, Ashari. 2011. Keragaan, Permasalahan dan Upaya Mendukung Akselerasi Program Swasembada Daging Sapi. Laporan Akhir Hasil Penelitian. PSE-KP. Bogor.

Ilham, N., Indraningsih, K.S., Elizabeth, R. 2018. Kinerja Berbagai Pola Usaha Pembibitan Sapi Lokal di Beberapa Daerah Pengembangan Sapi Potong. Jurnal. Analisis Kebijakan Pertanian. (AKP). Vol. 15. No. 1. 2017. Hal. 67-82. PSEKP. Bogor. Kementerian Pertanian. Jakarta.

Junaedi, M. 2012. Pemanfaatan Energi Biogas di Perusahaan Susu Umbul Katon 
Surakarta, Laporan Program Vucer 2002, Dikti-UMS, Surakarta.

Kamaruddin, A.S. 2008. Pembuatan dan penggunaan Unit Produksi Biogas Sederhana Skala Pedesaan. Penyuluh Pertanian Madya pada BPTP Makassar. http/www/blogs/energy/ Tanggal, 6 November 2018.

Kasryno, F. 2013. Politik Revitalisasi Pertanian dan Dampak Pelaksanaannya. Dalam Ariani et al. (Eds). Diversifikasi Pangan dan Transformasi Pembangunan Pertanian. Badan Litbang Pertanian, Kementerian Pertanian. Jakarta.

Kementerian Pertanian. 2013. Dokumen SIPP (Strategi Induk Pembangunan Pertanian) 2015-2045 mengenai: "Pertanian-Bioindustri

Berkelanjutan Solusi Pembangunan Indonesia Masa Depan.” Kementan. Jakarta

Ignas, Lidjang K., Amirudin P., Marawali, H.H 2015. Pendekatan Pengembangan Pertanian Bioindustri Berkelanjutan di NTT. Buku "Perspektif Pengembangan Model Pertanian Bioindustri." Badan Litbang Pertanian. Jakarta. IAARD Press. ISBN 978-602-691632-7.

Suharto. 2010. Konsep Pertanian Terpadu (Integrated Farming System) mewujudkan keberhasilan dengan kemandirian. Bahan Pelatihan
Revitalisasi Keterpaduan Usaha Ternak Dalam Sistem Usaha Tani. Bogor dan Solo, 21 Pebruari-6 Maret 2000. Puslitbang Peternakan Bogor. EAAP Publ. Denmark. 102: 117-120.

Supriadi, M. 2009. Pembuatan Kompos dari Limbah kandang dengan sistem Bumbung. Prosiding Seminar Nasional Teknologi Peternakan dan veteriner, Pusat Penelitain dan Pengembahgan Peternakan Bogor, Bogor, 13-14 Agustus 2009, hal. 808-814.

Suswono. 2013. Sambutan Menteri Pertanian dalam Buku SIPP (Strategi Induk Pembangunan Pertanian) 2015-2045. Kementerian Pertanian. 2014.

Sutisna, E. 2015. Perspektif Pengembangan Pertanian Bioindustri di Papua Barat. Buku "Perspektif Pengembangan Model Pertanian Bioindustri." Badan Litbang Pertanian. Jakarta. IAARD Press. ISBN 978-602-6916-32-7.

Thalib, A. 2008. Isolasi Dan Identifikasi Bakteri Asetogenetik Dari Rumen Rusa Potensinya Sebagai Inhibilor Metanogenetis. JITV. 12 (3): $197-$ 206.

Tuti, H. 2006. Biogas: Limbah Peternakan yang Menjadi Sumber Energi Alternatif. Buletin Ilmu Peternakan Indonesia- Wartazoa Vol. 10 No. 3. 2008, hal. 149-156. 